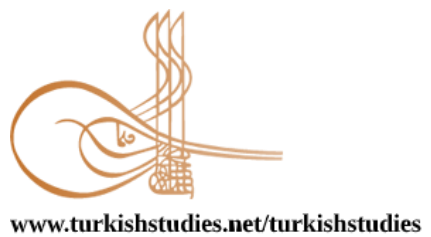

Turkish Studies

\title{
Tarih Boyunca Pandemiler ve Uluslararası Sisteme Etkileri
}

\author{
Pandemics through History and Their Impacts on the International System
}

\author{
Ebru Oğurlu*
}

\begin{abstract}
Global crises have the capacity to impact, change and transform the international system. One of those crises is epidemics and pandemics that are as old as the human history and cause serious economic, political, social and societal impacts. Similar to other pandemics such as the Black Death, smallpox, yellow fever, cattle plague and Spanish Flue that have been witnessing since the 14th century, the recent COVID-19 has turned into a global crisis with its potential to lead to serious impacts on the international system. COVID19 caused by novel corona virus (SARS-COV-2) is the first universal disaster of the twenty-first century. It was first reported in Wuhan province of China in December 2019. Although COVID-19 emerged as a global health problem, its impacts can be recognised in various dimensions of the international system ranging from health sector to supply chains from economic and social relations to global politics and international relations. As the first-breaking point of the 21st century, COVID-19 crisis has the capacity to transform the national, regional and global politics. It has revealed the internal contradictions within the ongoing neo-liberal system and urged a systemic transformation. Although the current conditions do not allow to make certain judgements about the scope and path of this transformation, the developments since the beginning of the crisis have suggested that the main dynamics that will shape the new world order would be the states. Post COVID-19 era signals a less globalised world where the main determining forces would be the strong states and national actions rather than international cooperation. This study tries to evaluate the possible economic and political impacts of COVID-19 pandemic on the international system and argues that this pandemic has become a vital test for the national, supra-national and international actors of the system among which, the states have appeared as the only ones that could prove their success under the unexpectedly chaotic circumstances.

Structured Abstract: Global crises are those that have the capacity to impact, change and transform the international system depending on the type of each specific crisis. One of those global crises is epidemics/pandemics that are as old as the human history and cause serious economic, political, social and societal impacts. All pandemics in the past have deeply affected the foundational basis, institutions and rules of the international system. The recent COVID-19 crisis, as one of the turning points of the 21 st century, should also be considered from this perspective. COVID-19, the disease caused by the novel corona virus named SARS-CoV-2, is declared as a pandemic by the World Health Organisation on 11 March 2020 after its spread to all parts of the world quickly and shortly. Although COVID-19 appeared as a global health problem, it shortly transformed into a multi-dimensional global crisis with its impacts on different levels of the international system including economic, political, social and societal among many others. It revealed the
\end{abstract}

\footnotetext{
* Doç. Dr., Lefke Avrupa Üniversitesi, İktisadi ve İdari Bilimler Fakültesi, Uluslararası İlişkiler Bölümü Assoc. Prof. Dr., European University of Lefke, Faculty of Economics and Administrative Sciences, Department of International Relations

Checked by plagiarism software Published/Yayın: 30 August/Ağustos 2020 CC BY-NC 4.0
} 
weaknesses and even vulnerability of the international system against a global risk factor more than ever before. It is supposed that this global multi-dimensional crisis would leave radical impacts on the whole international system similar to the earlier pandemics.

This paper adopts literature review, one of the qualitative research methods, as its methodology and presents the most symbolically important pandemics in history having transformative impacts on the international as well as national systems. Pandemics are global crises having the capacity to exert influence on different dimensions of the international system. One of the earliest examples of the pandemics having transformative capacity is the plague of the 14th century, the so-called Black Death which spread in the European continent and led to the death of almost one third of the whole population there. This reduction in the population resulted in radical societal and political repercussions. It shattered the basis of the then-feudal system in Europe, opened the way for the forthcoming Industrial Revolution and indirectly contributed to the European imperialism and colonialism. Smallpox was experienced between the 15th and 17th centuries. Although it was initially marked by suffering and death in Europe, then this biological event is said to have had a greater impact on European expansionism than gunpowder. Yellow fever of the late $18_{\text {th }}$ and early $19_{\text {th }}$ century turned in time into an almost intentionally deployed weapon targeting the Europeans and opened the way for the rise of the USA. The cattle plague of the late $19_{\text {th }}$ century played a preponderant role in the lives of the African societies by indirectly contributing to the extension of the influence of colonial states in the region. As one of the most recent pandemics, the Spanish flue of 1918 led to high death rates globally and resulted in the introduction of better and free health services in many states.

Similar to its earliest predecessors, COVID-19 has transformed into a multi-dimensional global crisis with its potential to influence both the national and international politics from different dimensions. Besides its short-term impacts on public health and public safety, its medium and long-terms impacts are inevitably expected to shape national, regional and global order in the post COVID-19 era. One of the issues on which the impacts of COVID-19 is being seriously felt is the effectiveness and efficiency of the international organisations referring to the suspicions about especially the first reactions of the World Health Organisation (WHO) vis-à-vis the quick spread of the corona virus globally. Although the WTO was set up in 1948 as the only globally authorised institution in health, it has become subject to the pressures of its member states over time. Under those conditions, COVID-19 has revealed the internal flaws of the WHO in terms of its capacity to cope with such a global health crisis. Not only the WHO but also most of the international/regional organisations as well as multilateral initiatives have become inadequate to deal with the negative effects of COVID-19. Rather the states have come to the fore as the most capable actors under those chaotic conditions by the help of their national policies within their closed national borders. Therefore, it seems highly possible that post COVID-19 system would be restructured on a state-centric basis both economically and politically.

Economic restructuring of the post COVID-19 era seems to be shaped along the Keynesian principles due to the loss of legitimacy of the existing neo-liberal economic order and its institutions in providing worldwide remedies to the current crisis. Rather, the states have become active in the economic life by introducing their economic revival packages to their public and welfare state spirit has re-appeared in the international stage after its long year disappearance. On the other hand, strong states have re-gained their popularity from the political perspective as well. In an era of uncertainty as well as due to the unreliability of the international and regional organisations, the states have appeared as the strongest and most reliable actors for their citizens which lead us to argue that COVID-19 has been revealing the contradictory tendencies of the international system. On the one hand, global cooperation, collectivity and solidarity have emerged as a necessity to deal with the challenges of this pandemic. On the other hand, the states have been trying to cope with it unilaterally rather than globally to survive and secure themselves. They have not refrained from any conflict and competition to reach to the limited supply of medical and pharmacological equipment as well as keep them at their national services. In that sense, post COVID-19 era signals a less globalised world where the main determining forces would be strong states, societal demands and national actions rather than individual liberties and global solidarity and cooperation. In case this tendency would endure, it is highly possible that political and economic order of the post-COVID-19 period would be shaped by the policies of the increasingly centralised states and national politics and global cooperative initiatives would be replaced by the strong and self-sufficient states and the competition between them.

Keywords: International Relations, COVID-19, World Health Organisation, Pandemic, Nationalisation, Globalisation, Nation State 
Öz: Küresel krizler, krizin niteliğine göre, uluslararası sistemi büyük ölçüde etkileyen, değiştiren veya dönüştüren krizlerdir. Söz konusu krizlerden biri; insanlık tarihi kadar eski olan ve uluslararası sistem üzerinde çok ciddi ekonomik, siyasi, sosyal ve toplumsal etkilere yol açan salgınlar/pandemilerdir. 14. yüzyıldan itibaren farklı dönemlerde gözlenen veba salgını, çiçek hastalığı, sarıhumma, Afrika sığır vebası ve İspanyol Gribi gibi bugün yaşanan COVID-19 pandemisi de uluslararası sistem üzerinde çok ciddi etkiler birakacak küresel bir krizdir. İlk olarak, Aralık 2019 tarihinde Çin'in Wuhan eyaletinde ortaya çıktığı belirtilen ve kısa zaman diliminde hızla tüm dünyaya yayılan, yeni tip korona virüsün (SARS-COV-2) neden olduğu COVID19 yirmi birinci yüzyılın ilk evrensel felaketidir ve küresel bir sağlık sorunu olarak ortaya çıkmış olsa da; sağlık sektöründen tedarik zincirlerine, ekonomik ilişkilerden sosyal ilişkilere, küresel siyasetten uluslararası ilişsilere kadar hayatın her alanını etkilemiştir. Mevcut düzende süregiden sorunları daha da görünür kılan, bu sorunlara yeni tartışma konuları da ekleyerek yirmi birinci yüzyılın ilk kırılma noktasını temsil eden bu kriz hem ulusal ve bölgesel hem de küresel siyaseti dönüştürecek kapasitededir. COVID-19 krizi ile birlikte mevcut şartlar altında süregiden neo-liberal düzenin kendi içindeki çelişkiler açığa çıkmış ve sistemsel bir dönüşüm kaçınılmaz hale gelmiştir. Bu dönüşümün ölçeği ve evrileceği istikamet hakkında kesin hükümler vermek zor olsa da pandeminin başından itibaren yaşanan gelişmeler yeni dünya düzenini şekillendiren temel dinamiğin devletler olacağını söylemektedir. COVID-19 sonrası dönem; güçlü devletlerin, bireysel özgürlükler yerine toplumsal ihtiyaçların ve uluslararası işbirliği yerine ulusal eylemlerin ağır basacağı daha az küresel bir dünyanın işaretlerini vermektedir. $\mathrm{Bu}$ çalışma COVID-19 pandemisinin uluslararası sistem üzerindeki olası siyasi ve iktisadi etkilerini değerlendirmekte; COVID-19'un sistemde yer alan ulusal, ulus-üstü ve uluslararası aktörler için hayati bir sınav olduğunu ve bu sınavdan varlığını kanıtlayarak çıkan en başarılı aktörün ulusdevletler olduğunu ileri sürmektedir.

Anahtar Kelimeler: Uluslararası İlişkiler, COVID-19, Dünya Sağlık Örgütü, Pandemi, Ulusallaşma, Küreselleşme, Ulus Devlet

\section{Giriş}

Küresel krizler, krizin niteliğine göre, uluslararası sistemi büyük ölçüde etkileyen, değiştiren veya dönüştüren krizlerdir. Söz konusu krizlerden biri; insanlık tarihi kadar eski olan ve uluslararası sistem üzerinde çok ciddi ekonomik, siyasi, sosyal ve toplumsal etkilere yol açan salgınlar/pandemilerdir. Aslında, tüm pandemiler küreselleşme tarihinin kritik kırılma noktalarıdır ve uluslararası sistemin temellerini, kurumlarını ve kurallarını derinden etkilemiştir. Bugün yaşanan kriz de yirmi birinci yüzyılın dönüm noktalarından biridir. Aralık 2019 tarihinde ilk defa şahit olunan yeni tip korona virüsün (SARS-CoV-2) COVID-19 hastalığ da bu kapsamda düşünülmesi gereken ve uluslararası sistem üzerinde radikal etkiler bırakması beklenen bir salgındır. 11 Mart 2020 tarihinde DSÖ tarafından pandemi ilan edilen COVID-19 bir sağlık sorunu olarak ortaya çıkmasına rağmen kısa sürede ekonomik, siyasi, sosyal ve toplumsal kırılma noktalarını tetikleyerek çok-yönlü bir krize dönüşmüş ve uluslararası düzenin, küresel bir risk unsuruna karşı zaafını her zamankinden daha fazla hissedilir derecede gözler önüne sermiştir. Söz konusu pandeminin özellikle, kamu sağlığı ve can güvenliğini ilgilendiren anlık etkileri yanında ulusal, bölgesel ve küresel düzeni şekillendirecek orta ve uzun vadeli etkileri de kaçınılmazdır.

Mevcut şartlar altında uluslararası düzenin/sistemin geleceği ile ilgili kesin hükümler vermek ve öngörüde bulunmak zor olsa da bazı tespitlerde bulunmak mümkündür. Öncelikle, COVID-19 pandemisinin çelişkili eğilimleri güçlendirdiğini söylemek yanlış olmayacaktır. Bir tarafta uluslararası işbirliği, dayanışma ve ortak mücadele zorunluluğu ortaya çıkmışken diğer tarafta devletler karşılıklı kazançtan ziyade kendi varlıkları ve güvenlikleri için sınırlarını kapatarak içlerine dönmekte ve küresel krizi ulusal önlemlerle aşmaya çalışmaktadır. Dış dünya ile bağlarını kopararak devletler ulusal çözümlere odaklanmakta; küresel dayanışma yerine sınırlı tıbbi ve farmakolojik teçhizat nedeniyle gerekli malzemeleri kendileri için elde tutma adına rekabet ve çatışma içine girmekten kaçınmamaktadır. Bu şartlar altında COVID-19 pandemisi güçlü devletlerin, bireysel özgürlükler yerine toplumsal ihtiyaçların ve uluslararası işbirliği yerine ulusal eylemlerin ağır bastı̆̆ daha az küresel bir dünyanın işaretlerini vermektedir. Bu yazının amacı; şimdiye kadar daha çok 
medikal etkilerinin tartışıldığ 1 pandemileri uluslararası ilişkiler bakış açısıyla sistemsel dinamikler çerçevesinde değerlendirmektir. Bu kapsamda hem yazılı basın hem de elektronik medya kaynaklarını kapsayacak şekilde yapılan literatür taraması neticesinde pandemilerin uluslararası sistemi farklı yönlerden etkileme kapasitesine sahip küresel krizler olduğunu tarihsel bir açıdan ortaya koyan bu çalışma esas olarak COVID-19 pandemisinin uluslararası sistem üzerindeki olası siyasi ve iktisadi etkilerini değerlendirmek ve yaşanan pandemi sürecinde hem siyasetteki hem de ekonomideki ulusallaşma eğilimlerini göstermektir. Bu anlayışın devam etmesi halinde kriz sonrası dönemde ekonomi-politiğin giderek merkezileşmesi ve devlet-merkezli bir anlayışla şekillenen yeni düzende küresel işbirliklerinin yerini ulusal siyasetin alması muhtemeldir. Bu çerçevede yazının birinci bölümünde 14. yüzyıldan itibaren yaşanan veba, çiçek hastalığı, sarıhumma, Afrika sığır vebası ve İspanyol Gribi gibi pandemilerin uluslararası sistem üzerindeki dönüştürücü etkileri tartışılmaktadır. İkinci bölümde ise, COVID-19'un uluslararası ekonomik ve siyasi düzlemdeki yansimaları analiz edilmektedir.

\section{Tarihteki Salgınlar ve Uluslararası Sisteme Etkileri}

Salgın hastalıklar tarihi değişimlerin ve gelişmelerin önemli bir parçasıdır. Sosyal, toplumsal ve siyasi gelişmeleri en az savaşlar, devrimler ve ekonomik krizler kadar ciddi bir şekilde etkilemiş ve hem ulusal kamu politikalarında hem de uluslararası sistemde kırılmaları beraberinde getirmiştir. COVID-19 krizinin yayılması ve bu krize verilen siyasi, ekonomik, kültürel ve toplumsal tepkiler de bazı tarihsel davranış kalıplarını yansıtmaktadır (Poos, 2020).

Örneğin, salgın hastalıklar modern devletlerin ortaya çıkışında rol oynayan etkenler arasındadır. Hastalık sürecinde bireyler bir sağlık otoritesine, gerekli kararların alınması ve uygulanması için yasama ve yürütme güçlerine, düzeni sağlamak için asker ve polis gücüne ihtiyaç duymaktadır. Tüm bu unsurlar aslında Thomas Hobbes, John Locke gibi düşünürlerin yüzyıllar önce ifade ettiği gibi insanların zor şartlar altında güvende olması için gücü elinde bulunduran bir otoriteye ihtiyaç duyduğunu göstermektedir. Söz konusu ihtiyaç bu otoriteyi elinde bulunduran devlet mekanizmasının doğuşunda ve gelişiminde etkili olmuştur (Karma, 2020). Benzer bir şekilde COVID-19 krizi de gücü elinde bulunduran merkezi devletlerin önemini bir kez daha ortaya çıkarmıştır. Bugün yaşanan COVID-19'un olası etkilerini kavramak ve tartışabilmek için geçmişte yaşanan salgınlara ve bu salgınların ulusal ve uluslararası sistemler üzerinde bıraktığı etkilere bakmak faydalı olacaktır.

Bu kapsamda akla gelen en eski referans noktalarından biri 14. yüzyılda yaşanan ve Avrupa'nın o tarihe kadar gördüğü en kötü felaket olarak nitelendirilen veba salgınıdır. Bu salgın bıraktığı sosyal ve kültürel izlerden sebep olduğu siyasal dönüşümlerden dolayı sadece tıbbi bir sorun olmaktan çıkmış, tüm Avrupa anakarasını etkileyen toplumsal bir olgu haline gelmiştir (Snowden, 2019: 31). Kita nüfusunun üçte birini öldürdüğü iddia edilen salgın neticesinde yaşanan nüfus kaybının hem toplumsal hem siyasal sonuçları olmuştur. Salgın dolayısıyla baş gösteren işgücü sıkıntısı hayatta kalan sağlıklı tarım işçilerinin toprak sahipleri karşısındaki gücünü ve gelirini artırmıştır. Böylece işçilerin toprak sahiplerinin borçlarını ödemek adına çalıştırıldığı feodal sistemin temelleri sarsılmış ve bu sarsılma Batı Avrupa'yı daha modern ve ticaret odaklı bir sisteme doğru itmiştir (Cherkaoui, 2020a: 3). Aynı zamanda, işgücü daha pahalı hale geldiği için toprak sahipleri maliyetleri düşürmek ve verimi artırmak adına tasarruflu teknolojilere yönelmiş ve bu alanda yatırımlara başlamışlardır. Böylece ileriki yıllarda yaşanacak olan sanayileşmenin, endüstri devriminin ve makineleşmenin önü açılmıştır. Diğer taraftan o zamana kadar riskli ve tehlikeli görülen deniz yolculukları ve keşifler de veba salgınından kaçmanın bir yolu olarak görülmüştür. Böylece, uzun deniz yolculukları mümkün ve daha olağan hale gelmiştir. Söz konusu gelişmeler, dolaylı yoldan da olsa, Avrupa'nın emperyalizmini ve sömürgeciliğini cesaretlendiren faktörler arasındadır (BBC News, 2020). Kısaca, vebadan etkilenen Avrupa teknolojiye yatırım yaparak, ekonomisini modernleştirerek ve dışa açılarak zamanla dünyanın en güçlü bölgelerinden biri haline 
gelmiştir. Daha genel bir çerçevede belirtmek gerekirse dünyanın hemen hemen her yerinde kendisini hissettiren veba salgını küreselleşmenin henüz bir olgu olarak bile var olmadığı bir dönemde bütün bir kürede sosyal, siyasal, toplumsal ve kültürel dönüşümlerin tetikleyicisi olmuş ve salgın hastalıkların yönetimi ve yönetilmesi adına modern devlet anlayışının ortaya çıkmasında rol oynamıştır (Balta, 2020).

Vebadan sonra 15. ve 17. yüzyıllar arasında gözlenen çiçek hastalığı da Avrupa'yı ciddi şekilde tehdit eden korkutucu bir hastalık olarak baş göstermiş ve zamanla diğer kıtalara da yayılarak etkisini tüm dünyada hissettirmiştir. Çiçek hastalığı hem coğrafi hem de siyasal ve toplumsal anlamda büyük dönüşümlere neden olmuștur. Öncelikle, yüksek oranda ölüme sebep olan bu salgın neticesinde işlenemeyen araziler ve büyük alanlar büyük ormanlara dönüşmüştür. Bitki ve ağaçlardaki bu muazzam büyüme karbondioksit seviyesinde azalma sağlayıp dünyanın geniş bölgelerinde sıcaklık düşüşlerine ve Küçük Buz Çağı olarak adlandırılan bir dönemin de ortaya çıkmasına neden olmuştur (BBC News, 2020). Diğer taraftan, yüksek oranda ölümlerin yaşandığ1 Amerika kıtasında boşalan alanlar Avrupalılar tarafindan doldurulmuş ve bu durum Avrupa'nın dünya çapında yayılmasına ve genişlemesine büyük bir katkı yapmıştır. Ancak Avrupalıların üstünlük kurduğu bu yerlerde çalıştırmak için ihtiyaç duyduğu yerli halkın yok olması Avrupalıları işgücü için başka coğrafyalara itmiştir. Bu şartlar altında yönünü Afrika'ya çeviren Avrupalılar, Amerika kıtasında köleliğin önünü açmış, özellikle bugünkü Haiti'yi de kapsayan geniş bir coğrafyada köleliği yerleşik hale getirmiştir (Snowden, 2019: 102, 103). Ancak bir salgın neticesinde köleleştirilen bu bölge bir başka salgın neticesinde kendi devrimini gerçekleştirme imkânı bulmuştur. 19. yüzyıl başında Amerika kıtasında görülen sarıhumma hem bu bölge özelinde hem de dünya genelinde kölelik ve sömürgecilik tarihinde önemli bir etkiye sebep olmuştur.

Amerika topraklarındaki Avrupalı sömürgecilerin ihtiyaç duydukları işgücünün Afrika'dan köle ticareti ile karşılaması bu topraklarda bir başka salgının tetikleyicisi olmuştur. Köleleştirilen Afrikalılar Amerika'da sarıhumma virüsünün yayılmasına neden olmuştur. Söz konusu salgının ve sonuçlarının en çok hissedildiği bölgelerin başında ise dönemin Fransa'sının ekonomik büyümesinin ve zenginliğinin temel kaynağını oluşturan Haiti gelmektedir (Snowden, 2019: 113-114, 139). Afrika kökenli bir hastalık olması nedeniyle sarıhumma hastalığına karşı bağışıklığı olmayan genelde Avrupalı özelde ise Fransız güçlerinin ölümü neticesinde Amerika kıtasındaki Afrikalı nüfus oldukça artmış ve bu nüfus 1791 yılında bölgede bulunan sömürgecilere karşı bir isyan hareketi başlatmıştır. İsyanın bastırılması için bölgeye gönderilen ek Fransız askerlerinin de salgın karşısında ağır kayıplar vermesi ve isyanın genişlemesi bölgenin kaderini etkilemiştir. Fransız ordusu bölgeden çekilmek zorunda kalmıştır ve Haiti bağımsızlığını ilan etmiştir. Bugünkü Haiti'de dönemin Fransız yönetimine karşı gelişen direniş ve devrim Latin Amerika'nın ilk bağımsızlık devrimi (Uyanık, 2014: 78) olması sebebiyle sembolik önemdedir. Sarıhumma salgınının bir neticesi olarak ortaya çıkan tüm bu gelişmeler aynı zamanda tarihi değiştirecek olayların da kapısını açmıştır. Kuzey Amerika'ya bir atlama tahtası olarak görülen Haiti'nin kaybedilmesi Fransa için Amerika'daki hedeflerinden vazgeçme anlamına gelmekteydi (Snowden, 2019: 139). Fransa'nın bölgeden çekilmesi ise kıtada ABD'nin büyümesine ve güçlenmesine olanak sağlayarak kıtadaki İngiliz egemenliğini sarsmış ve dünyanın geleceğini etkileyecek bir adım olmuştur. Aslında bir sağlık sorunu olarak başlayan sarıhumma salgını zaman içinde özellikle Avrupalı güçleri hedef alacak şekilde kurgulanan bir silaha dönüşmüştür (Snowden, 2019: 132).

19. yüzyıl sonlarında (1888-1897) gözlenen Afrika sığır vebası da dünya tarihini etkileyen bir başka salgındır. Hastalık özellikle Afrika Boynuzu, Batı Afrika ve Güneybatı Afrika bölgelerindeki toplulukları harap etmiştir. Ciddi oranda büyükbaş hayvan kayıplarına neden olan salgın adı geçen bölgelerde açlığa, toplumsal çöküşe ve salgından etkilenen bölgelerin boşaltılmasına neden olmuştur. Bölgede yaşanan bu karışıklık ve salgın şartları Avrupalı kolonyal devletlerin Afrika'daki hegemonyasını genişletmek için bir firsat sunmuştur (Phoofolo, 1993: 139). Aslında 1884-1885 Berlin Konferansı ile bu niyetlerini açıkça belli eden Avrupa ülkeleri salgınla ortaya çıan 
fiili durumdan faydalanmış ve yüzyıl sonunda Afrika'nın \%90'ınını ele geçirmiştir (BBC News, 2020). Netice itibarıyla sığır vebası olarak bilinen sağlık sorunu Avrupalı devletlerin kapsamlı sömürgeleştirme politikaları neticesinde ciddi siyasi sonuçlara neden olmuştur.

Küresel olarak etkili olan salgınlardan günümüze en yakın olanı ise 1918 yılında baş gösteren İspanyol Gribidir. Gribin ortaya çıktığı yer konusunda farklı bilgiler mevcut olsa da en gerçekçi bilgiler Amerika Birleşik Devletleri'ni işaret etmektedir (Roser, 2020). Birinci Dünya Savaşı'nın sonlarına doğru 1918 baharında görülen bu salgın kısa sürede tüm dünyaya yayılmış ve bir pandemi halini alarak 1920'li yılların başına kadar sürmüştür. Süren savaşın kötü barınma koşulları, yetersiz temizlik hizmetleri, sağlık hizmetlerinin aksaması gibi olumsuz etkileri ile salgının neden olduğu tahribat çok ciddi boyutlara ulaşmıştır (Byerly, 2010: 83-86; Price-Smith, 2009: 65). İspanyol gribinin siyasi, toplumsal ve askeri etkileri yanında en ciddi etkisinin nüfus üzerinde olduğu görülmektedir. Salgın ortalama 50 milyon kişinin hayatını kaybetmesine neden olmuştur. Dünya nüfusunun \%2.7'sine karşıllk gelen bu oran benzer salgınların neden olduğu kayıplarla karşılaştırıldığında oldukça yüksektir (Roser, 2020). İspanyol gribinin en önemli etkisi devletlerin sağlık sistemlerinde ve hizmetlerinde gözlenmiştir. Birçok ülkenin sağlık bakanlıkları yeniden düzenlenmiş ve kamu sağlığı stratejileri gözden geçirilmiştir. Sağlık hizmetlerinin ihtiyacı olan herkese ücretsiz sunulması anlayışı bu dönemde geçerlik kazanmıştır (Spinney, 2018).

Günümüzde yaşanan COVID-19 pandemisi ise yol açtığı ulusal etkilerin yanında uluslararası ve sistemik etkileri ile de tartışılmaktadır.

\section{COVID-19 ve Uluslararası Sistemin Geleceği}

Önceki salgınlara benzer bir şekilde küresel bir sağlık problemi olarak başlayan COVID-19 kısa bir süre içinde hem günlük hayatı hem de ulusal ve uluslararası gelişmeleri pek çok farklı açıdan etkileyen çok yönlü küresel bir kriz haline gelmiştir (Fischer, J., 2020).

COVID-19'un etkisini hissettirdiği alanların başında küresel siyaseti şekillendiren ana aktörlerden biri olarak kabul edilebilecek uluslararası örgütlerin ve çatı kuruluşların etkinliği gelmektedir. Küresel sağlık alanında tek otorite olarak kabul edilebilecek Dünya Sağlık Örgütü (DSÖ), 1948 yılında tüm insanların mümkün olan en yüksek sağlık düzeyine ulaşması ilkesi ile Birleşmiş Milletler çatısı altında kurulmuş; zaman içinde bütçesi, kaynakları, yol haritası dâhil işleyişi ile ilgili her konuda üye devletlerin baskısına açık hale gelmiştir (Busby, 2020). Üyeleri arasındaki uzlaşmazlıktan ve çıkar çatışmalarından dolayı olağan zamanlarda bile etkinliği ile ilgili ciddi endişelere neden olan DSÖ yaşanmakta olan krizin ilk evrelerinde krizi yönetme konusunda yetersiz kalmış ve varoluşsal sorgulamalara açık hale gelmiştir (Sachs, 1999). DSÖ ilk adım olarak 30 Ocak 2020'de uluslararası kamu sağlığı acil durumu ilan etmiş (World Health Organisation, 2020), bir pandeminin kriterleri çok önceden gözlenmiş olmasına rağmen hastalığın pandemi olarak ilan edilmesi 11 Mart 2020 tarihini bulmuştur (Fischer, R., 2020). Acil durum ilanı DSÖ'ye küresel krizle mücadele adına önemli yetkiler sağlasa da (Congressional Research Service, 2020) DSÖ’nün salgınla mücadele adına geç ve yetersiz kalması örgüte yöneltilen eleştirilerin başında gelmektedir. Otomatik yaptırım mekanizması bulunmayan DSÖ, aldığı kararların uygulanması için üye devletlerin işbirliğine ve taahhütlerine bağlıdır. Oysa ki örgüt içinde yer alan devletler bu şartlar altında dahi ortak bir eylem planı konusunda anlaşamamış, söz konusu anlaşmazlık DSÖ'yü bir savaş alanı haline getirmiştir (Dworkin, 2020). Bazı üyelerinin yörüngesinde hareket etmekle suçlanan DSÖ'nün bir başka sorunu ise finansal kaynaklarıdır. DSÖ'nün küresel sağlık sorunları ile mücadele etmekle yükümlü yıllık geliri oldukça sınırlıdır ve pek çok ülkenin kendi sağlık sistemleri için ayırdığ 1 bütçenin bile altındadır (Busby, 2020). Tüm bu yaşanan gelişmeler bugünkü pandemi krizi döneminde DSÖ içindeki "liderlik, bütçe, koordinasyon, etkinlik ve kararlılık" açıklarını ortaya çıkarmıştır (Morrison ve Hillman, 2018).

COVID-19 krizi ile birlikte sadece DSÖ değil uluslararası ve bölgesel örgütlerle çok-taraflı oluşumlar kendilerine en çok ihtiyaç duyulan kriz zamanlarda ne kadar etkisiz ve yetersiz kaldıklarını 
göstermişlerdir. Salgının yayılması ile birlikte BM Genel Sekreteri Antonio Guterres "pandeminin uluslararası barış ve güvenliğin korunması için bir tehdit teşkil ettiğini ve bu tehdidin küresel çapta sosyal rahatsızlık ve şiddete neden olarak hastalıkla mücadelede güç kaybına neden olacağını" (United Nations Secretary-General, 2020) açıklayarak küresel bir dayanışma ve anlaşmanın gerekli olduğunu vurgulamıştır. Ancak, ABD ve Çin arasındaki anlaşmazlıktan dolayı BM Güvenlik Konseyi ortak bir önerge yayınlayamamış, benzer şekilde G7 de yine iki ülke arasındaki söylem farkından dolayı ortak bir metin oluşturamamıştır (Borrell, 2020). Dünya üzerindeki bölgesel bütünleşme hareketleri için örnek olarak gösterilen ve üye ülkeleri üzerinde önemli bir etkiye sahip olduğu düşünülen $\mathrm{AB}$ de küresel krizle mücadele konusunda oldukça başarısız bir grafik sergilemiş; erken ve etkin tepki vermede kendisinden beklenmeyecek derecede zorlanmıştır (Nas, 2020; ArısanEralp, 2020).

Küresel yönetişimin imkânsızlığını ortaya çıkaran bu gelişmeler neticesinde devletler karantina, izolasyon, güvenli bölge, koruma hatları gibi kendi ulusal tedbirleriyle krize çare üretmeye çalışmıştır. Aslında gözlenen, geçmişte de çoğu defa görüldüğü gibi bir kriz ile karşı karşıya kalan devletlerin ilk çare olarak kendi içlerine dönmeyi tercih etmesi ve başvurdukları ulusalcı politikalarla giderek daha da içe kapanmasıdır. Netice itibariyle, uygulanan ulusal politikalar bir yandan devletin denetim ve gözetim gücünü artırırken diğer yandan bu gücü meşrulaştırmakta (Snowden, 2019: 8182); ulusal endişe ve korkulardan beslenen siyaset popülist söylem ve eylemlerini artırmaktadır (Poos, 2020). Bu sebeple, aşağıdaki bölümde tartışıldığı üzere korona sonrası yeni dünya düzeninin hem siyasi hem ekonomik ekseninin devlet-merkezli bir anlayışla oluşturulması mümkün gözükmektedir.

\subsection{COVID-19 Sonrası Yeni Ekonomik Dünya Düzen}

COVID-19 salgının neden olduğu en ciddi endişelerden biri yaşanacak ekonomik küçülmedir (Kahle, 2020). Bu kapsamda pandeminin olas1 ekonomik yansımalar1 2008 küresel finansal krizin etkileri ile karşılaştırılmaktadır. Joschka Fischer'in (2020) belirttiği gibi hem coğrafi anlamda daha yaygın olması hem de ekonominin tek bir sektörü üzerinde değil tüm ekonomik sistemi etkilemesi nedeniyle daha ciddi sonuçlar doğurabilecek kapasitedir. IMF yetkilileri de bu öngörüyü doğrulamaktadır (Georgieva, 2020).

Uluslararası ekonomik düzen pandemi öncesinde de pek çok yönden ciddi eleştirilere maruz kalmıştı (Borrell, 2020). Mevcut şartlar altında, ekonominin de-regülasyonuna (Özatıcı, 2020) dayanan neo-liberal kapitalist düzenin ortaya çıkardığı ekonomik ve dolayısıyla sosyal sorunlar yaşanan pandemi ile daha da akut hale gelmiştir. Aslında COVID-19'un ekonomik model olarak neo-liberalizmin bir krizi olduğunu söylemek mümkündür (Nunes, 2020). Özellikle 1980'lerin sonundan itibaren piyasanın üstünlüğü, minimal devlet, bireyselleşme, rekabet, özelleştirme ilkelerine dayanan neo-liberalizm dünyayı küresel bir piyasaya dönüştürmüştür (Lent, 2020; Harman, 2011: 5). Ulus-devletlerin giderek küçülmesine, sosyal güvenlik ağlarının zayıflamasına, sağlık gibi kamusal hizmetlere ayrılan bütçelerin azalmasına ve kamu hizmetlerinin "metalaştırılmasına" (Prashad, 2020) neden olan bu düzen devletlerin yaşanan pandemi gibi küresel sağlık sorunları ile müdahale gücünü zayıflatmıştır. Neo-liberal modelin gerektirdiği ve özellikle kemer sıkma politikalarına dayanan "yapısal dönüşüm stratejileri” neticesinde sosyal refah anlayışından uzaklaşılmış, kamu sağlığı başta olmak üzere kamu harcamalarına ayrılan pay azalmış ve ulusal sağlık sistemleri işlevsizleştirilmiştir (Labonté and Stuckler, 2015). Söz konusu politikalar ve yaklaşımlar neticesince, neo-liberal yönetimler bireylerin hayatlarını koruma ve geçimlerini sağlama gibi yönetimin en temel işlevlerini bile yerine getirmektede yetersiz kalmıştır (Saad-Filho, 2020). Bu kapsamda, COVID-19, neo-liberal ekonomik düzenin kendi içindeki çelişkileri açığa çıararak söz konusu sistemlerin ekonomik veya finansal kaynaklı olmayan küresel ve büyük ölçekli şoklar karşısında ne kadar yetersiz ve dayanıksız olduğunu ortaya koymuştur. Bu sebeple aslında 
COVID-19, sağlık krizi olarak ortaya çıkan ancak kökleri neo-liberal ekonomik düzenin şekillenmesinde bulunan siyasi bir tercihin neticesidir (Nunes, 2020; Schrecker ve Bambra, 2015).

Neo-liberal dünya düzeninin politik ve ekonomik kurumları COVID-19 pandemisi ile birlikte bir meşruiyet kaybı yaşamaktadır. Bu şartlar altında Keynesyen ekonomiyi ve politikayı1 hatırlayan devletler sosyal devlet anlayışı ile hareket ederek küresel çaptaki sistem değişikliklerini tetiklemektedir. Krize karşı ilk tepki olarak ülke sınırları ivedilikle ve kısa bir süre içinde tamamen kapatılmış, devletler stratejik ürünlerinin ihracatını yasaklamış ve özel sağlık kuruluşları kamunun hizmetine alınmıştır. Devletler, kamu sağlığı ve kamu düzenini sağlayabilmek için aldıkları olağanüstü tedbirlerle egemenliklerini pekiştirirken ekonomilerini canlandırma paketlerini de açıklamıştır. Neo-liberalizmin ve özel sektörün en dirayetli destekçileri bile yukarıda belirtilen devlet müdahalesini ve özel sektörün kurtarılması adına gerekli kamu harcamalarının yapılmasını savunur hale gelmiştir (Saad-Filho, 2020). Devletler, müdahaleleri sebebiyle değil neden geç müdahale ettikleri ve gerekli önlemleri zamanında almadıkları için eleştirilmektedir. Pandemi öncesi neo-liberalizm tarafindan tartışılması bile reddedilen evrensel temel gelir, vatandaşlık geliri, piyasaya devlet müdahalesi gibi bazı fikirler ve Keynesyen politikalar pandemi ile birlikte canlı ekonominin ve sosyal adaletin garantisi olarak kabul edilmektedir (Biscop, 2020; Lent, 2020). Çünkü, yaşanılan Covid-19 pandemisinin ortaya çıkardığı ekonomik yavaşlama, gerileme ve durgunluğun aşılması için devlet müdahalesi bir gereklilik olarak gözükmektedir. Bu sebeple, COVID-19 sonrası süreçte, neo-liberal bir anlayışın uzantısı olarak küreselleşmenin dayandığ serbest piyasa, minimal devlet ve özelleştirme ilkelerinin gözden geçirilerek küreselleşmenin tekrar düşünülmesi ve hem ekonominin hem de siyasetin yeniden düzenlenmesi bir zorunluluk haline gelmiştir (Byrialsen vd., 2020). Bu anlamda COVID-19'un ekonomik ve sosyal etkilerinin siyasi yansımaları da kaçınılmazdır.

\subsection{COVID-19 Sonrası Siyasi Düzen Tartışmaları}

Kenneth Waltz'un (2001) dediği gibi uluslararası sistem anarşik bir sistemdir. Merkezi bir otoritenin yokluğunda devletler herhangi bir tehdide karşı ayakta kalmak ve kendilerini savunmak zorundadır. Bazı yapısal zorunluluklar ve karşı karşıya kalınan tehditlerin türü devletler arasında işbirliğini gerektirse de (Keohane ve Nye, 2012; Oye, 1985) uluslararası sistemde var olan tedarik zincirleri, küresel dağıtım savaşları ve ülkelerin işbirliğinden önce kendi varlıklarını ve güvenliklerini garanti altına alacak şekilde kazanımlarını artırma çabaları küresel işbirliğini baltalamaktadır. Yaşanmakta olan COVID-19 pandemisi de söz konusu argümanları destekleyecek şekilde uluslararası işbirliği, dayanışma ve küresel yönetişimin temellerinin ne kadar kırılgan olduğunu gösteren çarpıcı bir örnek olmuştur. Krizin yayılma hızı ile orantılı olarak içlerine dönen devletler kendilerini izole ederek hayatta kalma mücadelesine girmiştir. Uluslararası ilişkiler disiplininin realist öğretisine uygun bir şekilde varlıkları ve güvenlikleri için içgüdüsel olarak bu yolu seçen devletler yaşanmakta olan olağanüstü şartları kullanarak güçlerini konsolide etmek firsatını bulmuştur.

Aslında 11 Eylül saldırıları sonrasında gözlenen güvenlikleştirme politikaları ve 2008-2009 finansal krizinin etkileri ile devletlerin uluslararası sisteme dönüşünün yolu açılmıştır. Bugün yaşanan sağlık sorunu da benzer benzer bir nitelikte ve güçlü devleti gerektirecek bir ciddiyettedir (Derviş ve Strauss, 2020). Çünkü bireyler olağanüstü durumlarda güçlü yönetim talep etmekte; mevcut belirsizlik ve güvensizlik hissi ile mücadele konusunda ulusuna dayanan, ulusunu koruyan ve her şeyi kontrol eden merkezi devletleri tek kurtarıcı olarak görmektedir. Rejimin türünden bağımsız olarak, güvenlikleri ve mevcudiyetleri söz konusu olduğunda vatandaşların devlet lehine özgürlüklerinden tavize hazır oldukları gözlenmektedir (Aydın, 2020: 40). Bu sebeple, mevcut şartlar altında küresel bir krizle başa çıkabilmek için "küresel plan, eylem ve yönetişim" (Karma, 2020) bir

1 Keynesyen politika, serbest piyasa ekonomisinin her zaman tam istihdamı sağlayamayacağ gerçeğinden hareketle, özellikle buhran dönemlerinde ekonomiye devletin müdahale etmesi gerektiği görüşüne dayanmaktadır. 
gereklilik olarak ortaya çıkmış olsa da pratikte gözlenen anlayış ve uygulamalar kriz sonrası eğilimin tam ters istikamette olabileceğini göstermektedir.

Pandeminin ortaya çıkardığı korku atmosferini kullanan özellikle radikal sağ ve popülist partiler küreselleşmeyi virüsün yayılımını hızlandıracak bir tehdit olarak göstermekte ve içe kapanmacı uygulamaları tek çare olarak görmektedir (Roberts ve Lamp, 2020). Mevcut istikrarsızlık kaynakları devletlere, korumacı ve milliyetçi politikalarını meşrulaşıırma zemini sağlamaktadır (Lent, 2020). Krizin ilk evrelerinde, Fransa'da Marie Le Pen, İtalya ile sınırlarını kapama çağrısı yaparak bu yönde ses yükselten ilk örneklerden biridir (Smith, 2020). Macaristan'da Victor Orbán pandemi şartları altında ülkeyi olağanüstü hal durumunda yönetebilmek için kendisine oldukça geniş yetkiler veren kanun teklifinin Nisan 2020 tarihinde yürürlüğe girmesini sağlamıștır (Svensson, 2020). İsviçre'de sağ kanat partilerden Lega dei Ticinesi adına konuşan Lorenzo Quadri da ulusal sınırların kapanması yönünde açıklamalarda bulunmuştur (Stevis-Gridneff, 2020). Almanya ve Fransa dâhil $9 \mathrm{AB}$ üyesi sınır kontrollerini uygulayabilmek için acil durum hükümlerini kullanmıştır (Laurent, 2020).

Söz konusu örneklerin bir kez daha doğruladığı üzere radikal kriz zamanlarını kendileri için bir firsat olarak gören radikal sağ hareketler COVID-19 pandemisini de bu açıdan değerlendirmiştir (Bilginer, 2020). Bu süreçte son yıllarda küresel siyasete hâkim olan otoriter, tek-taraflı, milliyetçi eğilimler COVID-19 pandemisi ile birlikte daha da derinleşmektedir (Wright ve Campbell, 2020). Sadece Avrupalı değil tüm devletler yaşanan kriz ve şok durumunu bir "istisna hali" (Agamben, 2006) olarak kabul edip bu istisna halini kendi güçlerinin konsolidasyonu için bir firsata çevirmektedir. Böylece yaşanan şok durumu (günümüzde pandemi) siyasi olarak manipüle edilmekte (Cherkaoui, 2020b: 9) ve devlet otoritesine bir firsat sunmaktadır. Normal şartlar altında toplumsal direnç gösterilebilecek gündem maddeleri ve otoriter politikalar toplum tarafindan sorgulanmadan kabul edilebilmektedir (Klein, 2007). Popülist söylemleri de kullanan otoriter yönetimler krizle başa çıkmanın tek yolu olarak her türlü imkân ve kaynağı elinde tutan merkezileştirilmiş devletleri göstermekte böyle bir şok ortamında da bireyler bu söylemleri kolayca kabul edip kendi içinde gücünü artıran ve ulusal duvarlarını kalınlaştıran devletlerini bir koruyucu olarak görmekte ve gönüllü olarak devletinin bu rolünü kabul etmektedir. Böylece popülizm ile birlikte yükselen milliyetçilik ve korumacılık büyük ve güçlü devlet anlayışını da geri getirmektedir (Fischer, J., 2020). Yaşanan tüm bu gelişmeler neticesinde COVID-19 pandemisi ile birlikte ulus devlet yakın geçmişimizde hiç olmadığı kadar büyük bir otoriteyle dünya sahnesine yeniden çıkabilmiştir (Özatıc1, 2020).

Başta DSÖ olmak üzere uluslararası ve uluslar üstü örgütlerin pandemi karşısındaki yetersiz ve etkisiz kalmış olması da kendi kendine yeten güçlü devlet anlayışını meşrulaştırmaktadır. Güçlü devletlerin ön plana çıkmasıyla uluslararası ilişkilerde daha geleneksel, devlet merkezli ve güçler arası rekabete dayalı bir uluslararası sistemin oluşması oldukça muhtemeldir. Burada önemli olan nokta güçlü devlet algısıdır. Gücünü otoriterleşme yönünde kullanan ve giderek daha baskıcı hale gelerek güçlenen devletlerden ziyade "tedarik zinciri sağlam, ekonomisi dirençli, halkına güven veren, güçlü kurumlara, başta sağlık olmak üzere altyapıya ve kriz yönetebilme becerisine sahip" olan güçlü devletler küresel ölçekte diğerlerinden olumlu olarak ayrışacaktır (Ulutaş, 2020: 12).

Diğer taraftan COVID-19 pandemisi uluslararası sistemdeki güçler dengesini de değiştirebilecek mahiyettir. Çin'in pandemi sonrasında iddia ettiği küresel rolü ve ABD ve Çin arasında yaşanması olası rekabet ve liderlik yarışı yeni düzeni şekillendirecek faktörlerin başında gelmektedir (Edel ve Rapp-Hooper, 2020, Campbell ve Doshi, 2020)). Uyguladığı en geniş, en sik1 ve en kapsamlı koruyucu tedbirler neticesinde Mart ayının ortasından itibaren salgını kontrol etmeye başlayan Çin, İspanya ve İtalya'ya tıbbi malzeme göndermiş; İspanya, Irak, İran ve daha pek çok ülkeye rehberlik hizmeti vermiştir. Tüm bu gelişmeler ışı̆̆ında Çin, Batı dünyasının kırılganlığını ortaya çıkarmış (Kaplan, 2020), İkinci Dünya Savaşı ertesinde Marshall Planı ile kurulan ABD-AB 
ortaklığına ciddi bir darbe vurmuştur. Aynı zamanda, Çin, dünya genelinde uyguladığ 1 kamu diplomasisi ve yardım kampanyaları gibi sahip olduğu yumuşak güç kaynakları ile yeni dönemdeki liderlik rolü için uluslararası kamuoyunun dikkatini çekmeyi başarmıştır (Cherkaoui, 2020b: 12). Bu çerçevede COVID-19 sonrası şekillenecek yeni düzenin en belirgin özelliklerinden birisi farklı güç merkezlerinin rekabetine dayalı düzensizlik yani “türbülansın” olacaktır (Duran, 2020: 30).

\section{Sonuç}

Salgın hastalıklar tarihi değişimlerin ve gelişmelerin önemli bir parçasıdır. Sosyal, toplumsal ve siyasi gelişmeleri ciddi bir şekilde etkileyerek hem ulusal kamu politikalarında hem de uluslararası sistemde kırılmaları beraberinde getirmiştir. 14. yüzyılda yaşanan veba krizi Avrupa'daki feodal sistemin temellerini sarsmış; Batı Avrupa'yı daha modern ve ticaret odaklı bir sisteme doğru itmiştir. Böylece, teknolojiye yatırım yapan, ekonomisini modernleştiren ve dışa açılan Avrupa zamanla dünyanın en güçlü bölgelerinden biri haline gelmiştir. 15. ve 17. yüzyıllar arasında gözlenen çiçek hastalığı Avrupa'nın dünya çapında yayılmasına ve genişlemesine büyük bir katkı yapmış, Amerika'da ise köleliğin yerleşik hale gelmesine neden olmuştur. Amerika kıtasındaki Afrikalı köleler arasında yayılan sarıhumma hem Latin Amerika'daki ilk bağımsızlık devrimini tetiklemiş hem de Avrupalı güçlerin bölgeden çekilmesine neden olarak ABD'nin büyümesinin ve güçlenmesinin önünü açmıştır. 19. yüzyıl sonlarında gözlenen Afrika sığır vebası Avrupalı kolonyal devletlerin Afrika'daki hegemonyasını genişletmesini kolaylaştırmıştır. Küresel salgınlardan günümüze en yakın olan 1918 İspanyol Gribi neticesinde ise ülkeler sağlık bakanlıkları yeniden düzenlemek ve kamu sağlığı stratejilerini gözden geçirmek zorunda kalmışlardır.

COVID-19 pandemisi yirmi birinci yüzyılın tüm insanlığ etkileyen ilk evrensel krizidir. Tarih boyunca gözlenen öncülleri gibi toplumsal, ekonomik, siyasi ve kültürel dönüşüm ve değişimlerin tetikleyicisi olarak önümüzdeki yıllarda hem küresel siyaseti hem de uluslararas1 ilişkileri temelden değiştirebilecek bir potansiyele sahiptir. COVID-19 krizi ile birlikte DSÖ dâhil olmak üzere uluslararası ve bölgesel örgütler ile çok-taraflı oluşumlar kendilerine en çok ihtiyaç duyulan kriz ortamlarında etkisiz ve yetersiz kaldıklarını göstermişlerdir. Bugün itibariyle yaşanan hem ciddi bir sağlık problemi hem de neo-liberal sistemin test edilmesidir. Piyasanın üstünlüğ̈̈, minimal devlet, bireyselleşme, rekabet, özelleştirme ilkelerine dayanan neo-liberal düzen devletlerin giderek küçülmesine, sosyal güvenlik ağlarının zayıflamasına, sağlık gibi kamusal hizmetlere ayrılan bütçelerin azalmasına neden olarak devletlerin yaşanan pandemi gibi küresel sağlik sorunları ile müdahale gücünü zayıflatmıştır. Netice itibariyle, kamu sağlığı başta olmak üzere kamu harcamalarına ayrılan pay azalmış ve ulusal sağlık sistemleri işlevsizleştirilmiş; neo-liberal yönetimler bireylerin hayatlarını koruma ve geçimlerini sağlama gibi yönetimin en temel işlevlerini bile yerine getirmekte yetersiz kalmıştır. Bu kapsamda, kriz öncesinde küçük adımlarla başlayan geniş kapsamlı toplumsal, siyasal, ekonomik dönüşümler kriz sonrası dönemde hızlanması beklenmektedir. Yaşananlar ekonomi yerine toplumu ve toplumsal dayanışmayı önceleyecek şekilde sistemsel bir dönüşümün gerekliliğini ortaya koymaktadır. Mevcut belirsizlikler altında kesin olan tek gerçek salgının yönetilmesi sürecinde etkinliklerini ve yetkinliklerini kanıtlayan güçlü devlet olgusunun geri dönmüş olmasıdır. Güçlü devletlerin ön plana çıkmasıyla uluslararası ilişkilerde daha geleneksel, devlet merkezli ve rekabete dayalı bir uluslararası sistemin oluşması da oldukça muhtemeldir. Özellikle Çin ve ABD arasındaki rekabet ve liderlik yarışı yeni oluşacak sistemi belirleyecek etkenlerin başında gelmektedir. COVID-19 pandemisi ile birlikte neo-liberalizmin bir meşruiyet kaybı yaşadığ 1 ve uluslararası aktörlerin ve oluşumların giderek işlevsizleştiği bir ortamda sistemin mutlak aktörleri olarak tekrar sahneye çıkan ulus devletler aynı zamanda Keynesyen ekonomiyi de hatırlayarak sosyal devlet anlayışı çerçevesinde küresel çaptaki sistem değişikliklerini tetiklemektedir. Pandemi öncesi neo-liberalizm tarafından tartışılması bile reddedilen evrensel temel gelir, vatandaşlık geliri, piyasaya devlet müdahalesi gibi bazı görüşler ve politikalar pandemi ile birlikte canlı ekonominin ve sosyal adaletin başlıca araçları olarak kabul edilmektedir. 
$\mathrm{Bu}$ kapsamda, COVID-19'un ekonomik ve sosyal etkilerinin siyasi yansımaları da kaçınılmazdır. 11 Eylül saldırıları ve 2008-2009 finansal krizinin etkileri ile sisteme dönüşlerinin yolu açılan devletler COVID-19 pandemisinin yayılma hızı ile orantılı olarak içlerine dönmüş ve bir hayatta kalma mücadelesine girmiştir. Varlıkları ve güvenlikleri için içgüdüsel olarak bu yolu seçen devletler yaşanan olağan üstü şartları lehlerine kullanarak güçlerini konsolide etmektedir. Yaşanan korku ortamı ve belirsizlik devlet otoritesine bir firsat sunmakta; krizle başa çıkmak için her türlü imkân ve kaynağ 1 elinde bulunduran tek aktör olan devletler de bu firsatı kullanmaktadır. Netice itibariyle büyük ve güçlü devlet anlayışını geri getiren gelişmeler pandemi sonrasında devlet odaklı kaotik bir düzenin ortaya çıkacağını ve bu kaos içinde ancak kendine yeten güçlü devletlerin hayatta kalabileceğini göstermektedir.

\section{Kaynakça}

Agamben, G. (2006). İstisna Hali. Çev. Kemal Atakay. Otonom Yayıncılık.

Arısan Eralp, N. (2020). Schuman Deklarasyonu'nun 70. Yılında AB'nin Korona ile Imtihanı ve Bu Sürecin Türkiye-AB Illişkilerine Etkisi. TEPAV Değerlendirme Raporu, Mayıs 2020, https://www.tepav.org.tr/upload/mce/2020/notlar/schuman_deklarasyonunun_70._yilinda_ abnin_korona_ile_imtihani_ve_bu_surecin_turkiyeab_iliskilerine_etkisi.pdf (Erişim Tarihi: 10.07.2020).

Atlı, A. (2020). COVID-19 Küreselleşmenin Sonunu Mu Getirecek? U. Ulutaş (Der.), COVID-19 Sonrast Küresel Sistem: Eski Sorunlar, Yeni Trendler içinde (ss.54-57). SAM Yayınları.

Aydın, M. (2020). COVID-19 ve Uluslararası Düzen. U. Ulutaş (Der.), COVID-19 Sonrası Küresel Sistem: Eski Sorunlar, Yeni Trendler içinde (ss.40-44). SAM Yayınları.

BBC News (2020). Koronavirüs: Tarihin aklşını değiştiren beş salgın. 20.03.2020, https://www.bbc.com/turkce/haberler-dunya-51970490 (Erişim Tarihi: 05.06.2020)

Balta, E. (2020). Kara Vebadan Koronavirüse Küreselleşme. Uluslararası İlişkiler Konseyi, 10.02.2020, https://www.uikpanorama.com/blog/2020/02/10/kara-vebadan-koronavirusekuresellesme (Erişim Tarihi: 05.06.2020).

Bilginer, E. M. (2020). Radikal Sağın Küresel Salgınla Sınavı: Çetrefilleşen Popülist Söylem. Panorama, Çevrimiçi Yayın, 19 Mayıs 2020, https://www.uikpanorama.com/blog/2020/05/19/radikal-sagin-kuresel-salginla-sinavicetrefillesen-populist-soylem/ (Erişim Tarihi: 10.07.2020).

Biscop, S. (2020). Coronavirus and Power: The Impact on International Politics, Egmont Institute - Security Policy Review, 126, March 2020, http://www.egmontinstitute.be/content/uploads/2020/03/SPB126-sven-corona260320.pdf?type $=$ pdf (Erişim Tarihi: 01.06.2020).

Borrell, J. (2020). The Post-Coronavirus World Is Already Here. European Council on Foreign Relations, April 2020, https://www.ecfr.eu/publications/summary/the_post_coronavirus_world_is_already_here (Erişim Tarihi: 07.06.2020).

Busby, J. (2020). What International Relations Tells Us about COVID-19. E-International Relations, 26.04.2020, https://www.e-ir.info/2020/04/26/what-international-relations-tells-us-aboutcovid-19 (Erişim Tarihi: 01.06.2020)

Byerly, C. R. (2010). The US Military and Influenza Pandemic of 1918-1919. Public Health Report, - Supplement, 125(3), 82-91. 
Byrialsen, M. R., Olesen, F. \& Madsen, O. M. (2020). COVID-19 and the Global Recession - The Imperative Need for a Keynes Solution, April 2020, https://www.researchgate.net/publication/341049572_COVID-

19_and_the_global_recession_-the_imperative_need_for_a_Keynes_solution (Erişim Tarihi: 08.07.2020).

Campbell, M.K. \& Doshi, R. (2020). The Coronavirus Could Reshape Global Order - China Is Maneuvering for International Leadership as the United States Falters. Foreign Affairs, July/August 2020, https://www.foreignaffairs.com/articles/china/2020-03-18/coronaviruscould-reshape-global-order (Erişim Tarihi: 08.07.2020).

Cherkaoui, M. (2020a). The Shifting Geopolitics of Coronavirus and the Demise of Neoliberalism Part 1. Al Jazeera Centre for Studies, 19.03.2020, https://studies.aljazeera.net/en/reports/shifting-geopolitics-coronavirus-and-demiseneoliberalism-\%E2\%80\%93-part-1 (Erişim Tarihi: 03.06.2020)

Cherkaoui, M. (2020b). The Shifting Geopolitics of Coronavirus and the Demise of Neoliberalism Part 2. Al Jazeera Centre for Studies, 22. 03.2020, https://studies.aljazeera.net/en/reports/shifting-geopolitics-coronavirus-anddemise-neoliberalism-\%E2\%80\%93-part-2 (Erişim Tarihi: 03.06.2020)

Congressional Research Service (2020), COVID-19: Global Implications and Responses. 08.05.2020, https://crsreports.congress.gov/product/pdf/IF/IF11421 (Erişim Tarihi: 07.06.2020).

Derviş, K., Strauss, S. (2020). What COVID-19 means for international cooperation. Brookings, 06.03.2020, https://www.brookings.edu/opinions/what-covid-19-means-for-internationalcooperation/ (Erişim Tarihi: 03.06.2020).

Duran, B. (2020). Koronavirüs Sonrası Yeni Bir Dünya Düzeni Mi, Düzensizliği Mi?. U. Ulutaş (Der.), COVID-19 Sonrası Küresel Sistem: Eski Sorunlar, Yeni Trendler içinde (ss. 29-34). SAM Yayınları.

Dworkin, A. (2020). How to repair multilateralism after covid-19. European Council on Foreign Relations, 22.05.2020, https://www.ecfr.eu/article/commentary_how_to_repair_multilateralism_after_covid_19 (Erişim Tarihi: 07.06.2020).

Edel, C, Rapp-Hooper, M. (2020). The 5 Ways U.S.-China Competition Is Hardening. Foreign Policy, 18.05.2020, https://foreignpolicy.com/2020/05/18/united-states-competitioncoronavirus-pandemic-tensions/ (Erişim Tarihi: 08.07.2020).

Fischer, J. (2020). The Politics of the Pandemic. Project Syndicate, 01.04.2020, https://www.projectsyndicate.org/commentary/european-union-covid19-politics-by-joschka-fischer-2020-04 (Erişim Tarihi: 05.06.2020).

Fischer, R. (2020). What's the difference between pandemic, epidemic and outbreak? The Conversation, 11.03.2020, https://theconversation.com/whats-the-difference-betweenpandemic-epidemic-and-outbreak-

133048?fbclid=IwAR2WK2jm6s6hu7gmLXDUPx9MSY4E4VdODxsdq2QM_u2dugFDD G7toXKVz40 (Erişim Tarihi: 01.06.2020).

Georgieva, K. (2020). The Great Lockdown: Worst Economic Downturn Since the Great Depression, International Monetary Fund - Press Release, 20/98, 23.03.2020, https://www.imf.org/en/News/Articles/2020/03/23/pr2098-imf-managing-directorstatement-following-a-g20-ministerial-call-on-the-coronavirus-emergency (30.05.2020). 
Harman S. (2011). Global Health Governance. Routledge.

Kahle, C. H. (2020). Aftershocks: The Coronavirus Pandemic and The New World Disorder, Stanford University - Freeman Spogli Institute for International Studies, 10.04.2020, https://fsi.stanford.edu/content/aftershocks-coronavirus-pandemic-and-new-world-disorder (Erişim Tarihi: 06.06.2020).

Kaplan, R. D. (2020). Why the pandemic should transform the way America thinks about war. The Washington Post, 08.04.2020, https://www.washingtonpost.com/opinions/2020/04/08/whypandemic-should-transform-way-america-thinks-about-war (Erişim Tarihi: 30.05.2020).

Karma, R. (2020), Coronavirus is not just a tragedy. It's an opportunity to build a better World. Vox, 10.04.2020, https://www.vox.com/2020/4/10/21213287/coronavirus-covid-19-pandemicepidemic-society-historian-nationalism-globalization (Erişim Tarihi: 05.06.2020)

Keohane R. O. \&Nye, J. S. (2012). Power and Interdependence. Longman.

Klein, N. (2007). The Shock Doctrine. Metropolitican Books.

Labonté, R. \& Stuckler D. (2016). The Rise of Neoliberalism: How Bad Economics Imperils Health and What To Do About It. Journal of Epidemiol Community Health, 70, 312-318.

Laurent, L. (2020). Salvini and Le Pen Don't Have a Coronavirus Cure, Bloomberg Opinion, 25.02.2020, https://www.bloomberg.com/opinion/articles/2020-02-25/salvini-and-le-pendon-t-have-a-european-coronavirus-cure (Erişim Tarihi: 02.06.2020).

Lent, J. (2020), Coronavirus spells the end of the neoliberal era. What's next? Open Democracy, 12.04.2020, https://www.opendemocracy.net/en/transformation/coronavirus-spells-the-endof-the-neoliberal-era-whats-next (Erişim Tarihi: 30.05.2020).

Morrison, S. J. \& Hillman, J. E. (2018). The Spanish Flu a Century Later: 2018 Is Not That Different from 1918.Center for Strategic\&International Studies, 09.03.2018, https://www.csis.org/analysis/spanish-flu-century-later-2018-not-different-1918 (Erişim Tarihi: 08.06.2020)

Nas, Ç. (2020). Koronavirüs Salgınının Yeni Merkez Üssü Avrupa: AB’nin Kriz Yönetimi Sınavı. Panorama, Çevirimiçi Yayın, 27.03.2020, https://www.uikpanorama.com/blog/2020/03/27/koronavirus-salgininin-yeni-merkez-ussuavrupa-abnin-kriz-yonetimi-sinavi (Erişim Tarihi: 10.07.2020)

Nunes, J. (2020). The COVID-19 pandemic: securitization, neoliberal crisis, and global vulnerabilization. Cadernos de Saúde Pública - Print Version, 36(5). https://doi.org/10.1590/0102-311x00063120

Oye, K. A. (1985). Explaining Cooperation under Anarchy: Hypotheses and Strategies, World Politics, 38(1), 1-24.

Özatıcı, C. (2020). Korona Salgını ve Neo-liberalizm Çökerken Keynesyenizmin Dirilişi. 21. Yüzyıl Türkiye Enstitüsü Politik-Sosyal-Kültürel Araştırmalar Merkezi, 24.04.2020, https://21yyte.org/tr/koronavirus-salgini/korona-salgini-ve-neo-liberalizm-cokerkenkeynesyenizmin-dirilisi (Erişim Tarihi: 10.07.2020).

Phoofolo, P. (1993). Epidemics and Revolutions: The Rinderpest Epidemic in Late NineteenthCentury Southern Africa. The Past and Present Society, 138, 112-143.

Poos, R. L. (2020). Lessons from past pandemics: Disinformation, scapegoating, and social distancing. 
https://www.brookings.edu/blog/techtank/2020/03/16/lessons-from-past-pandemicsdisinformation-scapegoating-and-social-distancing (Erişim Tarihi: 01.06.2020)

Prashad, V. (2020). A Socialist Cry for Civilisational Change: COVID-19 and the Failure of Neoliberalism. Economic \& Political Weekly, 14.04.2020, https://www.epw.in/engage/article/socialist-cry-civilisational-change-covid-19-coronavirus (Erişim Tarihi: 30.05.2020).

Price-Smith, A. T. (2009). Contagion and Chaos: Disease, Ecology, and National Security in the Era of Globalization. MIT Publishing.

Ramlal U. (2020). Politics of the Pandemic: The Failed Neoliberal Response to Coronavirus. Hampton Institute, 16.04.2020, https://www.hamptonthink.org/read/politics-of-thepandemic-the-failed-neoliberal-response-to-the-coronavirus (Erişim Tarihi: 30.05.2020)

Roberts, A. \& Lamp, N. (2020). Is the Virus Killing Globalization? There's No One Answer. Barron's, 15.03.2020, https://www.barrons.com/articles/is-the-virus-killing-globalizationtheres-no-one-answer-51584209741 (Erişim Tarihi: 02.06.2020).

Roser, M. (2020). The Spanish flu (1918-20): The global impact of the largest influenza pandemic in history. Our World In Data, 04.03.2020, https://ourworldindata.org/spanish-flu-largestinfluenza-pandemic-in-history (Erişim Tarihi: 08.06.2020).

Sachs, D. J. (2020). Bringing the World Health Organization Back to Health. Project Syndicate, 02.02.1999, https://www.project-syndicate.org/commentary/bringing-the-world-healthorganization-back-to-health?barrier=accesspaylog (Erişim Tarihi: 10.07.2020).

Saad-Filho, A. (2020). Coronavirus, Crisis and the End of Neoliberalism. Progress in Political Economy, 15.04.2020, https://www.ppesydney.net/coronavirus-crisis-and-the-end-ofneoliberalism/ (Erişim Tarihi: 30.05.2020).

Schrecker, T. \& Bambra C. (2015). How Politics Makes Us Sick: Neoliberal Epidemics. Palgrave MacMillan.

Smith, A. (2020). Coronavirus used by European populist right to challenge E.U. open borders, $N B C$ News, 07.03.2020, https://www.nbcnews.com/news/world/coronavirus-used-europeanpopulist-right-challenge-e-u-open-borders-n1 149491 (Erişim Tarihi: 02.06.2020).

Snowden, F. M. (2019). Epidemics and Society - From the Black Death to the Present. Yale University Press.

Spinney, L. (2018). The flu that transformed the 20th Century. BBC Future, 17.10.2018, https://www.bbc.com/future/article/20181016-the-flu-that-transformed-the-20th-century (Erișim Tarihi: 08.06.2020)

Svensson, S. (2020). Hungary: Orban uses pandemic to try and seize unlimited power. International Observatory Human Rights, 25.03.2020, https://observatoryihr.org/news/hungary-orbanuses-pandemic-to-try-and-seize-unlimited-power (Erişim Tarihi: 02.06.2020).

Stevis-Gridneff, M. (2020). Coronavirus: Europe's open borders threatened by spread of disease, Independent, 27.02.2020, https://www.independent.co.uk/news/world/europe/coronaviruseurope-open-borders-eu-italy-france-britain-germany-spain-a9362536.html (Erişim Tarihi: 02.06.2020).

Ulutaş, U. (2020). Koronavirüs Sonrası Küresel Trendler. U. Ulutaş (Der.), COVID-19 Sonrası Küresel Sistem: Eski Sorunlar, Yeni Trendler içinde (ss.10-19). SAM Yayınları. 
United Nations Secretary-General (2020). Secretary-General's remarks to the Security Council on the COVID-19 Pandemic [as delivered]. 09.04.2020, https://www.un.org/sg/en/content/sg/statement/2020-04-09/secretary-generals-remarks-thesecurity-council-the-covid-19-pandemic-delivered (Erişim Tarihi: 03.06.2020).

Uyanık, Ö. (2014), Latin Amerika'nın Devrimci Tarihi. Kaynak Yayınları.

Waltz, K. (2001). Men, the State and War-A Theoretical Analysis. Columbia University Press.

World Health Organisation (2020). Statement on the second meeting of the International Health Regulations (2005) Emergency Committee regarding the outbreak of novel coronavirus (2019-nCoV). 30.01.2020, https://www.who.int/news-room/detail/30-01-2020-statementon-the-second-meeting-of-the-international-health-regulations-(2005)-emergency-

committee-regarding-the-outbreak-of-novel-coronavirus-(2019-ncov) (Erişim Tarihi: 01.06.2020).

Wright, T. \& Campbell, K. M. (2020). The Coronavirus is Exposing the Limits of Populism. The Atlantic, 04.03. 2020, https://www.theatlantic.com/ideas/archive/2020/03/geopoliticscoronavirus/607414 (Erişim Tarihi: 02.06.2020). 